\title{
Mycosis Fungoides and Sezary Syndrome T1a TNM Finding v8
}

National Cancer Institute

\section{Source}

National Cancer Institute. Mycosis Fungoides and Sezary Syndrome T1a TNM Finding v8. NCl Thesaurus. Code C141332.

T1a (patch only). (from AJCC 8th Ed.) 